\title{
O CRISTO CÓSMICO CURANDEIRO NO PÊNDULO DOS DEMÔNIOS DA ANTROPOSOFIA
}

\author{
Raquel Littério de Bastos ${ }^{1}$
}

\begin{abstract}
Resumo: $\mathrm{O}$ texto articula a cosmologia antroposófica à arte gótica alemã da passagem do século XIV para o XV, apresentando uma interface com a estética da cura que remonta aos dias atuais na medicina neorromântica desta ciência espiritual europeia. A obra de arte ícone da cura na Antroposofia é a imagem do Cristo Curandeiro ou Cristo Cósmico, presente no Retábulo de Issenheim. Esse Retábulo está exposto para meditação e apreciação no museu Unterlinden, em Colmar, na regiáo da Alsácia-França (próxima a cidade de Dornach-Suíça, sede da Sociedade Antroposófica). Na cosmologia desta ciência espiritual, o Cristo Cósmico é considerado o único capaz de metamorfosear a doença em cura. A imagem do Cristo presente na parte do Retábulo intitulada $A$ Ressureição foi reelaborada pela Antroposofia, transformando-a em um arquétipo do elemento do meio, solucionador do conflito, evocando o mittler do romantismo alemão, das disputas entre as estimulantes forças luciféricas e arimânicas nos processos de cura.
\end{abstract}

Palavras-chave: Arte sacra; Cura; Estética; Antroposofia.

THE COSMIC CHRIST CURIUM IN THE PENDULUM OF THE DEMONS OF ANTHROPOSOPHY

Abstract: The article articulates anthroposophical cosmology with German Gothic
art from the $14^{\text {th }}$ to the $15^{\text {th }}$ century, in an interface with the aesthetics of cure
that goes back to the present day in the neo-Romantic medicine of this European
spiritual science. The icon work of art of cure in Anthroposophy is the image of
the Christ Cure or Cosmic Christ present in the Retable of Issenheim. This Retable
is exhibited for meditation and appreciation at the Unterlinden museum in Colmar,
Alsace-France, near Dornach-Switzerland, headquarters of the Anthroposophical
Society. In the cosmology of this spiritual science the Cosmic Christ is considered

1 Pesquisadora de pós-doutorado no PPGSC FMB Unesp de Botucatu, São Paulo, Brasil. E-mail: raquelbastos@yahoo.com e raquelitterio@gmail.com.

Debates do NER, Porto Alegre, Ano i 9, N. 35, P. 27I-29I, Jan./JUl. 20 i 9 
the Single capable of metamorphosing the disease into cure. The image of the Christ present in the part of the Retable entitled The Resurrection was reworked by Anthroposophy, transforming it into an archetype of the middle element, solver of the conflict, evoking the mittler of German Romanticism, of the disputes between the stimulating Luciferic and Ahrimanic forces in cure processes.

Keywords: Sacred art; Cure; Aesthetics; Anthroposophy.

\section{INTRODUÇÃO}

O artigo debruça-se em articular a cosmologia antroposófica à arte gótica alemã em uma interface com a reelaborada construção cultural da concepção de saúde e cura que remonta aos dias atuais nas medicinas neorromânticas. O objetivo foi ocupar-me em descrever as origens do simbolismo do Cristo Cósmico e/ou Curandeiro na pintura do gótico tardio germânico, demonstrando como a imagem é reelaborada pela Antroposofia, transformando-a em um arquétipo do elemento do meio, solucionador do conflito, evocando o mittler do romantismo alemão, das disputas entre as forças luciféricas e arimânicas nos processos de cura.

A Antroposofia é uma ciência espiritual europeia conhecida amplamente no Brasil por intermédio das escolas Waldorf e dos medicamentos da Weleda. Esta ciência espiritual foi elaborada no início do século $\mathrm{XX}$, possuidora de uma cosmologia esotérica e evolucionista. Por meio de sua cosmologia descrita no percurso etnográfico realizado para a pesquisa doutoral sobre a concepção de cura na Antroposofia, entre os anos de 2012 e 2016, realizado no Brasil e na Suíça, em uma instituição de saúde e em duas comunidades antroposóficas, foi possível compreender as principais teorias sobre o adoecimento e a cura da humanidade.

Apenas para situar o leitor, trata-se de uma etnografia multissituada, realizada entre os anos de 2012 e 2016, em três Ramos Antroposóficos (Tobias e Jatobá, no Brasil, e Rose Croix, na Suíça), na Clínica Tobias, no 
bairro de Santo Amaro, em São Paulo; no bairro rural da Demétria, com a comunidade de antropósofos que habitam o Ramo Jatobá e o Branch Rose Croix, e na cidade de Vevey, próximo a Lausanne, na Suíça francesa. Ramo ou Branch - em francês - é a expressão utilizada pela Sociedade Antroposófica para designar o coletivo de antropósofos e para a organizaçáo de serviços considerados apropriados aos adeptos, como as escolas Waldorf e as farmácias da Weleda. A etnografia descreveu a rotina das terapias da alma, do espírito e do corpo na Clínica Tobias, em 2012, a vida em comunidade na Demétria, em 2013, e o convívio entre os moradores do Branch e os eventos realizados na casa responsável pela biblioteca antroposófica desta coletividade, em 2014, objetivando, continuamente, descrever a concepção de uma cura estética e uma estética da cura nesta ciência espiritual, expressa na corporeidade dos adeptos com distintas nacionalidades e construçóes culturais (Bastos, 2018).

Em uma interlocução com o conceito antropológico de agência, o artigo apresenta os três principais encontros etnográficos com a imagem do Cristo Cósmico sob a premissa de que o objeto de arte tem uma função sociorrelacional, no qual está inserido (Gell, 1998, p. 7), sendo mediador das relaçóes fronteiriças entre a arte, a espiritualidade e a saúde na comunidade antroposófica. A noçáo de espiritualidade utilizada no texto emergiu dos interlocutores como forma de autoidentificação e resistência a comportamentos dogmáticos.

\section{OS ENCONTROS COM A IMAGEM}

Instalada em parede central na sala de jantar, a imagem do Cristo Cósmico ocupava lugar de status, destacado dos demais adornos. Articulado com a sala de estar, o espaço destinado às refeiçóes era composto por uma ampla mesa para acomodar várias pessoas. No entorno da imagem do Cristo Cósmico, a decoração da sala ostentava uma intensa gama de símbolos religiosos oriundos da Índia e do Japáo, souvernires e regalos das viagens realizadas pelos moradores da casa. 
O primeiro encontro com a imagem do Cristo Cósmico ocorreu na moradia de uma senhora baiana na Comunidade Antroposófica da Demétria, no interior do estado de São Paulo. Para essa senhora, adepta da Antroposofia, mas associada também a outras concepçóes filosóficas e religiosas, inclusive as religióes de matriz africana decorrentes de sua origem regional e étnica às quais tinha a maior devoção. A presença da imagem a igualava às demais famílias brancas e europeias, permitindo a entrada nos variados grupos sociais dessa comunidade rural. Despossuídos de proveniência europeia que os legitimasse prontamente na Demétria, ou um montante considerável de dinheiro que os auxiliasse na manutenção do estilo de vida sugerido aos adeptos, essa senhora buscava um equilíbrio entre as distintas concepçóes religiosas, hábitos e tradiçóes europeias, realizando uma bricolagem dos afetos e obrigaçóes necessárias para se manter no grupo.

O equilíbrio evocado pela imagem do Cristo Cósmico naquela sala de jantar em nada se aproximava da ideia de mittler do romantismo alemão, mas fendia o cerco exigente do exercício da cultura germânica. Por meio da legitimidade que a imagem em sua sala de jantar suscitava, essa senhora baiana podia inaugurar uma outra Antroposofia, uma Antroposofia baiana.

Os outros dois encontros com a imagem do Cristo Cósmico ocorreram na Europa, em 2014, na casa da comunidade de Vevey, especificamente no consultório da terapia nomeada de Quirofonética ${ }^{2}$, e o terceiro encontro na cidade de Colmar, na França, onde está exposto o Retábulo de Issenheim.

$\mathrm{Na}$ casa da comunidade antroposófica de Vevey, habitavam suíços, franceses e brasileiros. Para as tarefas cotidianas, a senhora dona do casario dispunha de funcionários portugueses. Entre esses portugueses, havia uma jovem que prestava serviços terapêuticos e, após conseguir grandes resultados retrocedendo um quadro inflamatório bastante severo de uma artrose

2 A Quirofonética é uma terapia corporal que reúne recursos da massagem e da fala. A fundamentação e a aplicação prática da Quirofonética são descritas extensamente no livro de Alfred Baur O Sentido da Palavra: no Princípio era o Verbo, São Paulo: Editora Antroposófica, 1992.

Debates do NER, Porto Alegre, ANo i 9, N. 35, P. 27I-29I, Jan./JUl. 20 i 9 
diagnóstica como um excesso das influências arimânicas, foi convidada para montar o seu primeiro consultório em um dos cômodos da casa. Ainda iniciante na prática terapêutica e na língua francesa, essa jovem foi posta a uma prova de fogo: apresentar os benefícios da prática aos demais antropósofos suíços. O resultado foi desabonador, os adeptos mais antigos demonstraram aborrecimento e insatisfação com a apresentação, ora porque suspeitavam do aumento repentino de terapias associadas aos preceitos desta ciência espiritual, ora por ouvir da terapeuta um francês claudicante. Triste e preocupada em ter uma possível perda do status que havia conseguido a duras penas, suportando os rompantes da dona da casa, que era também seu mecenas, financiando suas necessidades, trouxe para o consultório a imagem do Cristo Cósmico.

A jovem portuguesa era católica e, em um ambiente luterano, procurava ocultar os gestos e as expressóes de sua religiosidade. Pressionada pela dona da casa a ser gentil com os demais moradores, prontificou-se em realizar gratuitamente a terapia enquanto eu estivesse sobre o mesmo teto. Interessada em etnografar mais um trabalho terapêutico, aceitei a oferta, apesar do sentimento constrangedor de também ter sido pressionada a fazê-los nos moldes da dona da casa.

A imagem do Cristo Cósmico não estava emoldurada, não era um quadro, e foi colocada em um cavalete improvisado, logo atrás da maca onde os corpos eram terapeutizados. Um improviso, uma urgência. A jovem portuguesa precisava ser aceita entre os antropósofos suíços para ampliar o seu leque de clientes. A imagem evocava a ordem no caos. $\mathrm{O}$ caos de ser estrangeira e estar sob a avaliação rigorosa e etnocêntrica dos adeptos locais. A jovem desconhecia o mittler do Romantismo Alemão assim como desconhecia a complexidade da ciência espiritual antroposófica. Reclusa em sua sala de terapia, antes de iniciar o procedimento, pedia ao Cristo Cósmico o poder da cura e orava com devoção em busca de coragem.

No museu Unterlinden, em Colmar, na região da Alsácia-França, próxima a Dornach-Suíça, ocorreu o último encontro com a imagem do Cristo Cósmico. O museu está localizado em um convento de monjas dominicanas 
do século XIII, onde apresenta fronteiras porosas entre a arte e a religiosidade, a devoção dissipa-se e a arte se erige. O Retábulo de Issenheim tem uma estrutura imponente e é a obra principal do museu. Situada no centro do Unterlinden, a obra exerce uma atraçáo centrípeta nos visitantes que orbitam o museu. Organizado de forma deliberada, o museu dispóe cadeiras em frente à obra para os visitantes que desejarem viver a experiência da contemplação do Retábulo. Existem visitantes que passam horas contemplando a bela obra, sem a intençáo de alcançar a cura sugerida pela Antroposofia ou o equilíbrio do Romantismo Alemão.

A administração do museu distribui informativos sobre o Retábulo, mas não faz menção ao Cristo Cósmico ou à Antroposofia, essas informaçôes reelaboradas ficam ocultas, perceptíveis apenas aos iniciados nesta ciência espiritual. No entanto, alguns adeptos da Antroposofia consideram a ida até o Unterlinden indispensável à formaçáo espiritual. Essa peregrinação é bastante discreta e não assume contornos religiosos. A visita é facilitada pela proximidade com a sede oficial da Antroposofia, o Goetheanum, na Sociedade Antroposófica, em Dornach, na Suíça. Os adeptos com maior poder aquisitivo vão a Dornach para os eventos acadêmicos e cursos profissionalizantes e depois, váo até a França para conhecer pessoalmente a imagem original do Cristo Cósmico no Retábulo de Issenheim. Os antropósofos náo expressam uma devoçáo com a imagem. A contemplaçáo estética da arte se dá com o objetivo de alcançar uma ética.

\section{O CRISTO CÓSMICO CURANDEIRO NO RETÁBULO DE ISSENHEIM}

A imagem do Cristo do Retábulo de Issenheim envolto por seus seres diabólicos (Quant, 2016) é, na Antroposofia, a obra-prima que estreita a relação entre cura, arte e espiritualidade. $\mathrm{O}$ envolvimento da arte com as religiốes em processos de cura não é uma temática nova. Já na antiguidade, os artistas compartilhavam a esfera dos magos com o mesmo status de 
um médico, isso porque buscava-se, por meio da arte, expressar o hyeros (sagrado), considerando que esta era uma hierofania (revelação do sagrado) e principalmente uma hierogogia (condução do indivíduo ao sagrado). As cores teriam a função de uma ponte de ligação da humanidade aos deuses, favorecendo os processos de cura.

A obra Cristo do Retábulo de Issenheim foi feita pelo pintor alemão Matthias Gothart Niethart, conhecido como Matthias Grünewald, que nasceu 1528, e foi o precursor do expressionismo e um dos maiores pintores germânicos do gótico tardio. O Retábulo de Issenheim, a mais famosa obra do pintor alemão Matthias Grünewald, é uma obra grandiosa, composta por nove painéis que se encaixam e cobrem o altar. Na sua primeira parte, apresenta São Sebastião (era invocado como protetor contra a peste), e Santo Antônio (padroeiro da ordem religiosa que dirigia o hospital e mosteiro), nas laterais; a crucificação no centro e o Cristo morto embaixo (Higuet, 2009).

O retábulo foi realizado para o Hospício de Issenheim, o qual, como todos os conventos da Ordem dos Hospitalários Antoninos, tinha por vocação tratar de enfermos e doentes. No Convento dos Antoninos, eram recolhidas as vítimas de uma doença, misteriosa na época, que se abateu sobre a região da Alsácia por meio de uma intoxicação pelo esporão do centeio. Incurável, a doença consumia a pele e provocava mau cheiro. As pessoas com essa doença tinham dores horríveis e muitas vezes enlouqueciam de dor. Os doentes que chegavam ao convento eram levados para a capela onde ficava o Retábulo de Issenheim, havendo uma identificação com a dor da crucificação, pintada na parte externa do Retábulo.

Quando o moribundo estava prestes a morrer, e somente neste momento, o frontispício do altar era aberto e as imagens se modificavam totalmente, apresentando a imagem $A$ Ressurreição, na hora da morte do doente. A Figura A Ressureição, no canto direito da imagem do Retábulo, na Antroposofia, é chamada $O$ Cristo Cósmico.

De acordo com os estudos de Higuet (2009), o Retábulo foi encomendado pelo preceptor do convento dos Antoninos para substituir um retábulo mais antigo. O políptico (retábulo com compartimentos fixos e 
móveis) é uma ilustração das atividades dos religiosos, que se dedicavam ao cuidado com os doentes, em particular com os pestíferos. O padroeiro, santo Antáo, ocupa um lugar de destaque. O Retábulo destinava-se a todos os que entravam no hospício que tinham perante a imagem de Cristo de confessar-se e comungar, e a conduzi-los a meditarem e rezarem perante as imagens da Bíblia. Para Witzell (2017), há, no Retábulo de Issenheim, um poder disciplinador, pois remete à descrição de técnicas do suplício, de sofrimento gradual; a morte não é apenas a suspenção do direito de viver, mas é o estágio final de uma série de sofrimentos atrozes que, segundo Foucault (2010), configuram estratégias de controle dos corpos.

Os antropósofos nomearam a imagem de Cristo Cósmico em uma clara alusão à evoluçáo planetária proposta em sua cosmologia esotérica. Nessa cosmologia, o Cristo Cósmico é, ao mesmo tempo, o sol e o elemento mercurial, o estágio mais evoluído em que a humanidade poderá atingir. A Antroposofia concebe a morte como o próximo passo da jornada, como um estágio de evoluçáo espiritual, o movimento de "cruzar o limiar" e modificar a cadeia de encarnaçôes.

$\mathrm{Na}$ sequência, temos o Retábulo de Issenheim: 
Figura 1 - Retábulo de Issenheim fechado, em Colmar, na França.

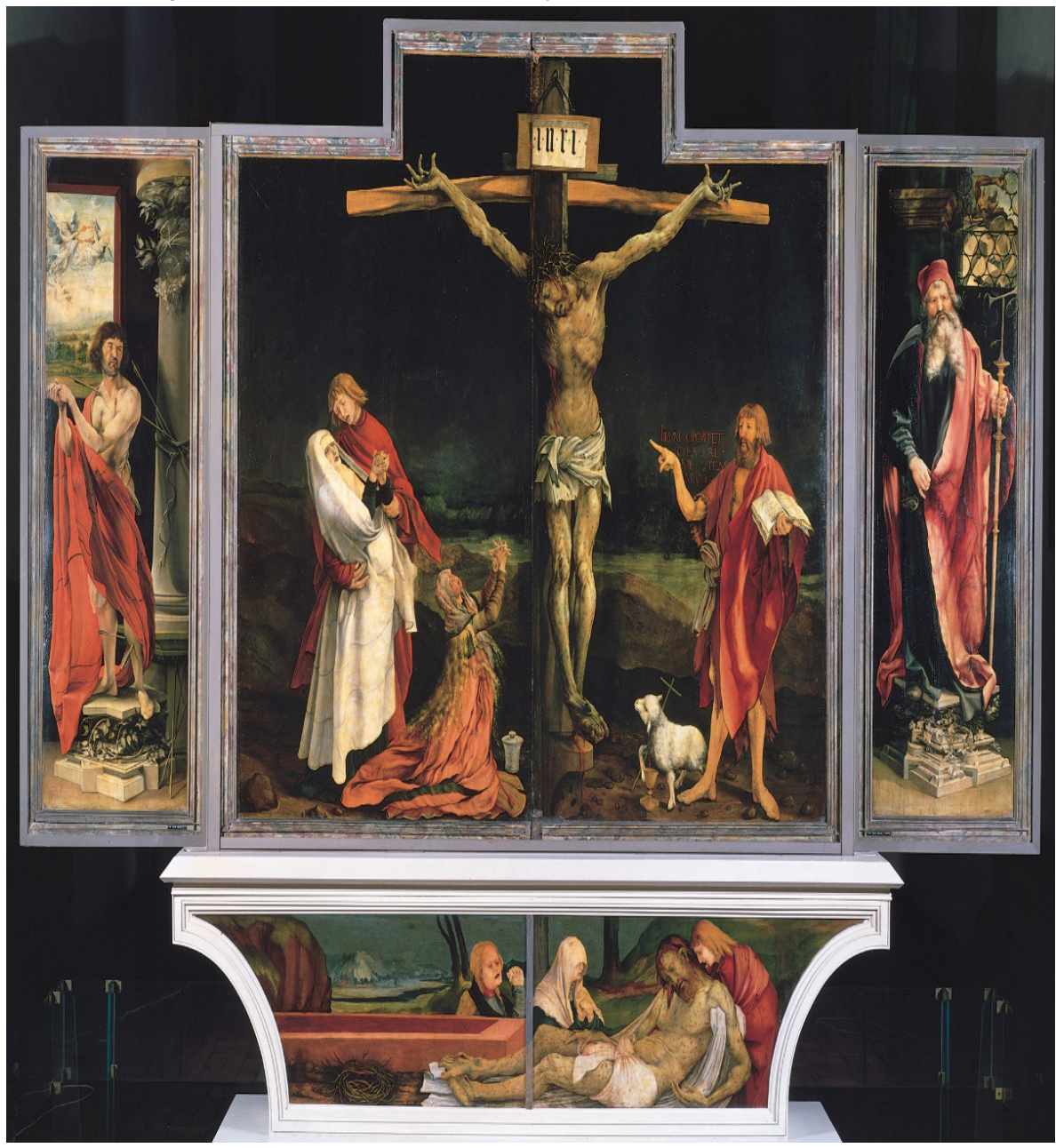

Fonte: Museé Unterlinden. Disponível em: http://www.musee-unterlinden.com/ collections/lexperience-le-retable-dissenheim/. Acesso em 2015. 
Para a Antroposofia, a doença alavancaria esse movimento irrefutável do enfermo em sua busca pela cura: um caminho a ser trilhado sem lamentaçôes, com coragem edificante. A biografia de quem adoece seria revista e superada durante o processo de doença e morte. A cura poderia ocorrer com a morte, em que o enfermo poderia ir para além de si, e elevar a sua existência a um nível superior, um novo nascimento.

Figura 2 - Retábulo de Issenheim aberto, em Colmar, na França.

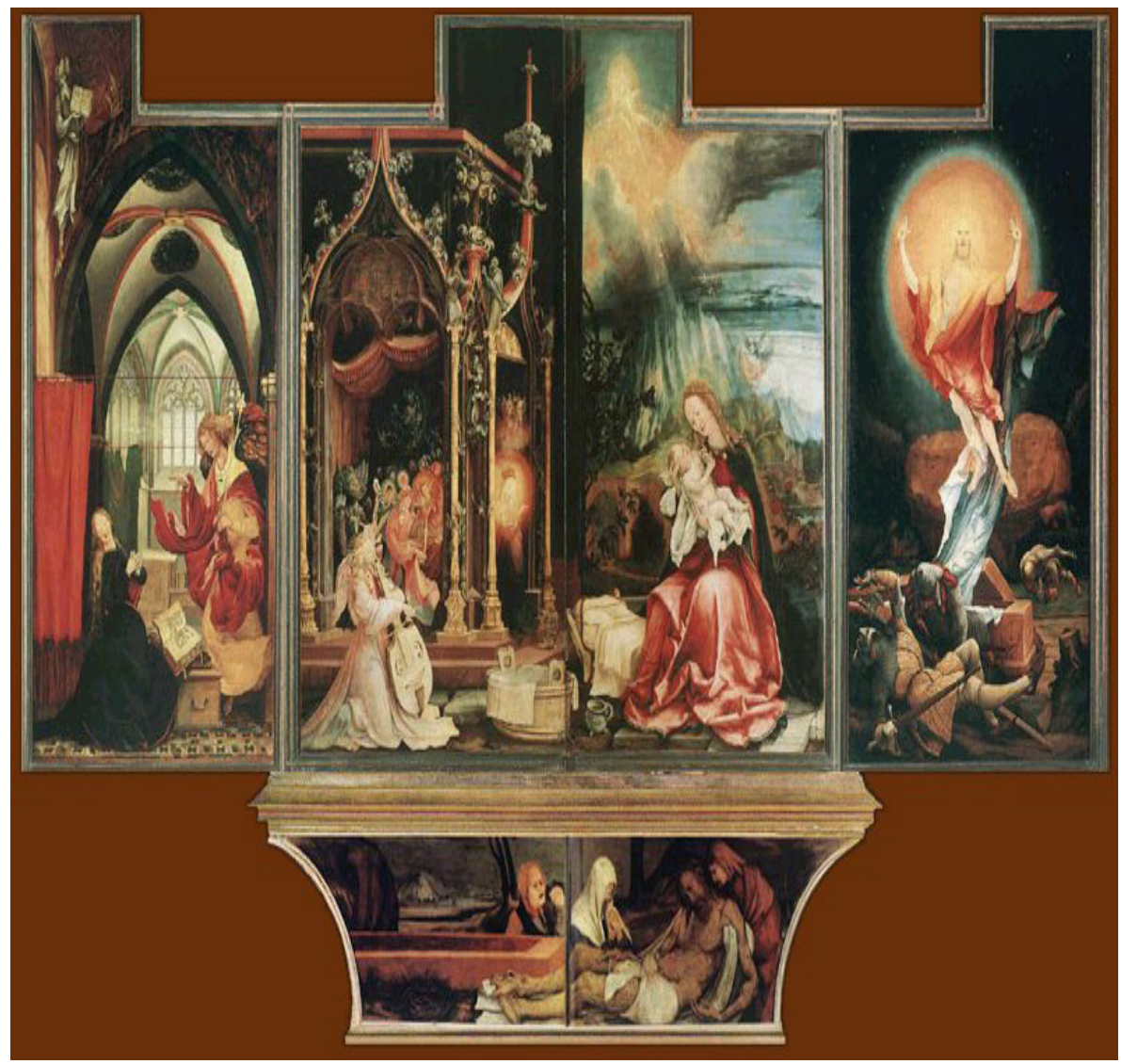

Fonte: Museé Unterlinden. Disponível em: http://www.musee-unterlinden.com/ collections/lexperience-le-retable-dissenheim/. Acesso em 2015. 
Figura 3 - Detalhe do Retábulo de Issenheim, A Ressureição.

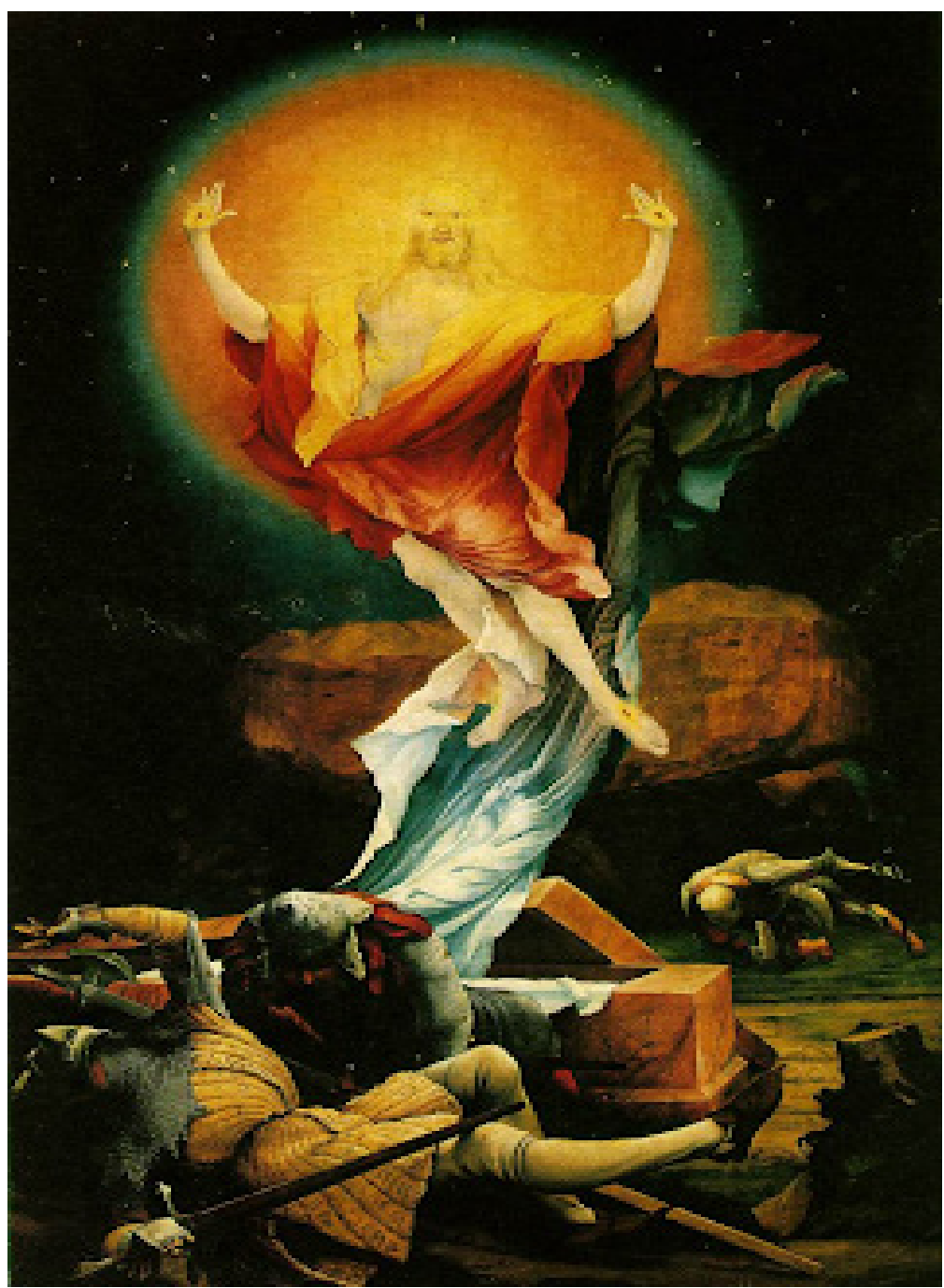

Fonte: Museé Unterlinden. Disponível em: http://www.musee-unterlinden.com/ collections/lexperience-le-retable-dissenheim/. Acesso em 2015. 
A arte de Grünewald inscreve-se na tradição cristã da Idade Média: a mística alemã dos séculos XIV e XV, a pintura e a escultura do fim do gótico foram para ele o ponto de partida temático e formal. Segundo Higuet (2009), há na obra dele uma progressão da expressão que não tem equivalente na pintura da sua época, em que o papel da cor é preponderante. As formas apresentam um caráter simbólico e também expressionista (Gaehtgens, 2009 apud Higuet, 2009). Philippe Lorentz chamou a atenção para a força expressiva dos "drapés" (pregas e movimentos nas roupas das personagens) na pintura do gótico tardio flamengo e alemão.

Para Higuet (2009), a diversidade e a desmedida dos tecidos de Grünewald têm o poder de transportar o contemplador para um outro mundo. Os casos mais espetaculares são a roupa do Arcanjo Gabriel na representação da Anunciação e o lençol de Cristo no quadro da Ressurreição, que parecem flutuar. "Pintor expressionista, Grünewald sabe tudo o que pode fazer com a manipulação dos drapés para exacerbar o pathos ou para solenizar os mistérios da fé" (Béguerie-de Paepe, 2007, p. 30, grifos do autor).

Com o Retábulo "acaba a era da devoção e começa a era da arte» (Hans Belting, 2011, p. 76). O Retábulo de Issenheim inaugura uma nova compreensão da imagem: a estética. A reforma rejeitou a obra de arte como objeto de devoção. As transformações do sistema iconográfico germânico no século XVI estavam ligadas aos acontecimentos da reforma, nos quais todos os grandes artistas foram envolvidos em diversos graus. Os grandes artistas da época, como Dürer, Grünewald, Baldung, Grien, Cranach, Holbein, Altdorfer, encontravam-se no ponto de intersecção entre os dois meios de expressão: a palavra e a imagem; assim como estáo no cruzamento de dois mundos: o medieval e o moderno. A relação visual entre o sujeito e o objeto - a imagem é uma simples imago e não mais uma pessoa ou um ídolo (Higuet, 2009).

As técnicas e os temas modificaram-se movendo a destruição iconoclasta, que se colocava na reforma. O Cristo, “[...] torna-se presente por meio de uma ação sacramental do olhar, a vista se sacraliza” (Higuet, 2009, p. 10). A imagem situa-se no prolongamento da hóstia, da qual é uma imitação fiel. O complexo artístico do retábulo que combina painéis pintados e esculpidos, 
está em relação direta, espacialmente, tematicamente e liturgicamente com o sacrifício eucarístico.

No tumulto da reforma protestante, a crucifixão de Grünewald ilustra a angustia de uma sociedade germânica desestabilizada pelas fomes, as epidemias, as guerras, as errâncias da igreja. A sensibilidade de artista de Grünewald percebe a tempestade que está se formando. Para o pintor, como para uma boa parte dos seus contemporâneos, em um mundo caótico, a salvação só pode revelar-se numa leitura de fé da Escritura (La crucifixion, 2007). A renomeação do Cristo do Retábulo em o Cristo Cósmico Curandeiro pela Antroposofia, também antecede as tempestades da Segunda Guerra Mundial. O Cristo que se destinava às doenças físicas incuráveis, evocando também o movimento na possibilidade de transcendência espiritual em situaçóes críticas que os algozes do nazismo trariam.

O Cristo Cósmico Curandeiro do Retábulo de Issenheim simboliza a alma, em sua posição intermediária, sempre mercurial. Os românticos, como Goethe, concebiam, por herança dos alquimistas, a noção de mittler, o elo que liga as duas polaridades e resolve o conflito. $\mathrm{O}$ mittler, o intermediário entre essas duas polaridades fundamentais, o meio entre espírito e matéria, entre espírito e natural-biológico, é a alma.

\section{CRISTO CÓSMICO CURANDEIRO COMO O MITTLER MERCURIAL}

Retomando a premissa de que o objeto de arte tem uma função sociorrrelacional na qual está inserido, a imagem do Cristo Curandeiro ou Cristo Cósmico pode ser pensando como um mediador das relaçóes fronteiriças entre a arte, a espiritualidade e a saúde na comunidade antroposófica. O status da imagem de obra de arte ícone da cura, possibilita refletir sobre as distintas agências que esta assume em diferentes situaçóes e mesmo quando os indivíduos estão no mesmo continente. 
Primeiro, preciso frisar que a expressão Cristo Curandeiro surge em tom jocoso no livro de Peter Washington, O Babuino de Madame Blavatsky, sobre os gurus ocidentais, como Rudolf Steiner. Entre os interlocutores, o termo utilizado é "Cristo Cósmico" e, em sua cosmologia, é considerado o único capaz de metamorfosear a doença em cura. Essa cura levaria os adeptos a uma ascensão angelical, desde que a virtude da coragem se manifestasse por meio de um enfrentamento estético do sofrimento, transformando os percalços da vida em uma experiência edificante, sem lágrimas e sem lamúrias.

De acordo com a literatura produzida pelos intelectuais orgânicos da Antroposofia, esta ciência espiritual inspirou-se em antigas tradiçôes cristãs, contudo as origens antroposóficas não são colocadas de forma clara, tornando misteriosas as fontes sobre as quais se apoia. É provável que essa indefinição seja o resultado de uma bricolagem das mais variadas teorias esotéricas e cristãs. Fundamentados nessas tradiçóes, os antropósofos elaboraram uma cosmologia com seres divinos que disputam lado a lado a consciência humana, beneficiando o equilíbrio entre as forças. Esses seres divinos são considerados seres atrasados em sua evolução espiritual e foram denominados seres arimânicos e luciféricos, controlados pelas entidades Arimâ e Lúcifer (Setzer, 2011).

A doença é considerada fundamental na evolução espiritual da humanidade. Os processos individuais de cura são importantes, pois sem eles a humanidade não alcançaria sua meta planetária, eis o porquê da expressão "Cristo Cósmico". Neste projeto cósmico, a doença não é compreendida pelos interlocutores como um desajuste orgânico, mas todos os tipos de transtornos humanos que necessitem de resolução. Os humanos são então auxiliados por estes espíritos inferiores, na busca de um equilíbrio pendular entre as forças arimânicas e luciféricas que agem como coadjuvantes neste desenvolvimento espiritual (Husemann; Wolff, 1984, p. 32 apud Floriani, 2014, p. 10).

O corpo na Antroposofia expressa essa performance pendular entre as forças demoníacas e o Cristo Cósmico Curandeiro como o elemento mercurial, o mittler. Fundamentado em uma cosmologia cristã e evolucionista, o corpo na Antroposofia desenvolveu-se em várias etapas planetárias de evolução 
espiritual da humanidade. O corpo obedeceria uma organização trimembrar e quadrimembrar ${ }^{3}$. Para este artigo, resgato apenas organização trimembrar, pois essa organização resgata o elemento mercurial da antiga tríade alquímica de Saint-Martin, um ocultista do século XVIII, representada pelo tríplice movimento - salinização, sulfurizarão e mercurialização, inúmeras vezes citada nas obras de Rudolf Steiner, revivendo a relação entre os elementos: sal (tudo que coagula e endurece), enxofre (tudo que tende à dissolução) e mercúrio (o equilíbrio entre as duas polaridades). Uma tríade com a triplicidade da natureza - corpo, alma e espírito.

O equilíbrio humano dependeria desta trindade teológica: ahrimânico (sal) - crístico (mercurial) - luciférico (enxofre). Essa trindade é bastante referenciada pelos interlocutores no Brasil e na Suíça. Segundo os adeptos, o corpo, em relação ao espírito, pode ser sal, considerando que é matéria, mas também pode ser, mudando-se o contexto, enxofre, considerando que é inconsciente em relação ao espírito. Este último pode ser, em certo contexto, sal e, em outro, enxofre.

A introdução do elemento do meio resolveria o conflito do opostocomplementares, ou seja, o elemento mercurial, que pode ser a alma ou o espírito, mas sempre representando o cristo. Nessa tríade - sal, mercúrio e enxofre - a polaridade arquetípica de todas as coisas (contração/expansão) é resolvida por um terceiro elemento que as harmoniza, as equilibra - o mercurial (Moraes, 2007, p. 54).

Equilibrar o conflito leva-me a pensar nas agências que a imagem do Cristo Cósmico assume nos dois primeiros encontros. Lugares distantes, Brasil e Suíça, mas com agências tão próximas. Nas duas situações, a imagem

3 Na quadrimembração, surge outra forma analógica de ver da Antroposofia, através da qual os fenômenos são compreendidos a partir de uma referência básica, arquetípica: a dos quatro elementos empedocleanos - terra, água, ar e fogo. Terra seria um qualificativo que evocaria solidez, peso, substância, densidade (Moraes, 2007). Na quadrimembração dos corpos, as situaçôes patológicas estão nas metamorfoses de cada uma dessas organizaçóes, como no desgaste da organização vital, o excesso da organização anímica, o afastamento da organização do Eu. 
aparece instrumentalizada por ambas as mulheres para legitimar a permanência e o status no grupo. A jovem portuguesa, ao suplicar o poder da cura em frente à imagem do Cristo Cósmico, solicita também o acesso ao grupo que legitima seu trabalho terapêutico. Seu sucesso profissional é a garantia da sua permanência entre os suíços. Para ela, não é fundamental compreender o mittler do Romantismo Alemão, suas raízes católicas são suficientes para acionar os efeitos benéficos da dissolução das barreiras culturais.

Para a senhora baiana na Demétria, basta colocar a imagem na parede central, não há necessidade de valer-se do Cristo Cósmico com tanta veemência, seu estrangeirismo situa-se apenas no terreno dos hábitos e valores. As almas dessas duas mulheres enfrentavam desafios semelhantes de pertencimento. Almas que necessitam intermediar situações de conflito, limpar as sombras, metamorfosear a crise por meio do elemento mercurial.

$\mathrm{Na}$ alquimia, o mercúrio é capaz de dissolver qualquer metal, tornado mais lúcido, claro e sem sombra, limpando as impurezas, retirando do interior dos metais menos perfeitos a sua natureza oculta. A confecção do mercúrio é considerada para os alquimistas um segredo da natureza, por isso mal se pode entende-lo, exceto por uma revelaçáo divina ou por um outro. $\mathrm{O}$ mercúrio teria o poder de atrair a alma dos corpos vivos e levá-los para Plutão.

Mas e o mittler? Para os românticos, como Goethe, que concebiam por herança dos alquimistas, a noção de mittler e o elo que liga as duas polaridades para a resolução do conflito. $\mathrm{O}$ mittler é o intermediário entre os extremos que no Romantismo Alemão, e toda expressão estética como a literatura, a poesia e a pintura destinada a corroborar para com uma interpretação mais ampliada do humano por meio de uma Naturphilosophie.

Entre os interlocutores com origem europeia e germânicos, a compreensão da imagem do Cristo Cósmico aproximava-se do conceito de mittler, modificando sua agência. A percepçáo da imagem como cura dilui-se no discernimento do que é a humanidade com suas mazelas. $\mathrm{O}$ mittler é a própria natureza evocando a conciliação das forças pendulares que nos movem no desenrolar da vida, apaziguando os conflitos para a retomada do equilíbrio nas situaçóes adversas. Para esses interlocutores, a imagem assume, em combinaçáo com 
as inspiraçóes românticas, uma agência mais comprometida com um estilo de vida estético e, por consequência, ético. Uma filosofia do bem viver por meio da ponderação e atenção aos ritmos do cotidiano.

No romance de Goethe As afinidades eletivas, o mote do poeta romântico são as afinidades entre os elementos químicos. Maas (2010) em sua análise literária descreve as várias facetas que o Mittler assume. Mittler é o nome dado a um personagem cuja função na narrativa é, como o próprio nome indica, a de mediador ou conciliador. Em sua primeira aparição em cena, Mittler é apresentado como "esse homem engraçado" (der drollige), "aquele homem estranho" (der wunderliche Mann), "o hóspede bizarro" (der närrischer Gast) - adjetivos muito pouco adequados a um homem cuja função deveria ser a de apaziguar conflitos domésticos. O personagem Mittler vive com o firme propósito de não se demorar em nenhuma casa onde não houvesse nada para apaziguar ou dar assistência. O nome Mittler o teria forçado a seguir estranhas determinaçóes. (Goethe, 1992, p. 34).

Mensageiro celestial, Hermes ou Mercúrio, Mittler não vem, entretanto, da parte de Ottilie. Vem por "impulso próprio": "Eduard ficou, porém, aborrecido e mal-humorado ao perceber que Mittler não viera a pedido dela" (Goethe, 1992, p. 129). Apesar de ser o mensageiro, este náo transmite as novas, não permite o processo de comunicação e interpretação do discurso do outro. Vem por vontade própria, embaralhando o processo de comunicação, trazendo à experiência um elemento estranho, capaz de alterar o comportamento original dos atores. Para Heinz Schlaffer, a presença de Mittler é, literalmente, mortal: ele desencadeia a morte do pastor quando do batizado da criança; dispara o mecanismo que leva à morte de Ottilie por meio de seu discurso inconveniente sobre o sexto mandamento, e é ele, por fim, o primeiro a deparar-se com Eduard morto (Schlaffer, 1981, p. 219 apud Maas, 2010, p. 12).

A função do elemento mercurial, do mittler, do Cristo Cósmico Curandeiro, não é eliminar o mal. O elemento mercurial é volátil, é fluido, como Hermes com seus pés alados. Não pode ser explicado e muito menos evocado. O mittler possui vontade própria, é um hóspede bizarro, um mensageiro 
que faz revelaçóes incômodas. A cura para os alquimistas está em produzir, internamente, o próprio elemento mercurial. $\mathrm{O}$ mal não pode ser eliminado, apenas subjugado. O mittler é o mediador, o conciliador, o equilíbrio pendular entre as forças demoníacas, não o algoz do mal. Na performance pendular na Antroposofia, o mal é compreendido entre os interlocutores como um bem deslocado no tempo e no espaço, mas não necessariamente um malfeitor.

Estou inclinada a elucubrar se o Retábulo Issenheim, em sua totalidade e não somente a imagem do Cristo Cósmico, ao apresentar os martírios e as tentaçóes de Santo Antáo, promovia uma agência disciplinadora dos desejos humanos, uma estratégia de controle dos corpos, segundo Foucault (2010). Esse pensamento leva-nos além. leva-nos aos espaços apertados que essas duas mulheres, a senhora baiana e a moça Preciosa, procuravam se moldar para ocupar. A imagem do Cristo Cósmico estava aqui e ali para lembrá -las, constantemente, pela estética, a ética do autodisciplinamento para a adequação ao grupo.

Equilibrados, os corpos não podiam estar nem duros nem moles. $\mathrm{O}$ endurecimento por influência arimânica, por exemplo, teria sua causa na vida emocional, no âmbito da alma, em decorrência de atitudes pedantes, materialistas e permeadas por uma razão árida. $\mathrm{O}$ amolecimento estaria associado às influências luciféricas, com ideias repletas de imaginação e de fantasia. Uma batalha entre Árimã e Lúcifer para aprisionar o ser humano: o primeiro, no espírito, desligando-o da matéria, e o outro na matéria, desligando-o do espírito (Setzer, 2011).

Para Setzer (2011), Goethe intuiu a possibilidade de transformar o mal em bem. Na cena em que Fausto perguntou a Mefistófeles: quem é este? a aquele que representava Árimã, e recebeu a resposta Ich bin ein Teil jener Kraftldie stets das Böse will/und stets das Gute schafft, ("Eu sou uma parte daquela força que sempre quer o mal, mas sempre cria o bem”4). Para tanto,

4 Tradução do autor. 
o mal não deve ser eliminado, mas sublimado, transformado em bem na busca de uma estética comportamental e corporal.

\section{CONSIDERAÇÕES FINAIS}

A sofisticada proposta de uma cura estética na Antroposofia inspira-se em ícones e narrativas de imortal beleza legitimando as práticas terapêuticas firmadas em sua complexa cosmologia. A obra prima de Grünewald, o Retábulo de Issenheim, é ainda hoje objeto de arte de grande apreciação. Alojada em antigo convento transformado em museu, garante a todos os visitantes a experiência da meditação e contemplação sensibilizada para a instigante mística alemã dos séculos XIV e XV do gótico tardio. A Antroposofia, ao reinterpretar as obrar de arte, operacionalizam-nas em agências direcionadas para a manutenção da organização ética por meio da beleza estética.

$\mathrm{O}$ ato de abrir e do fechar do Retábulo evoca movimento, elemento tão caro aos românticos, afinal, a resolução dos conflitos assim como a cura da humanidade está em percorrer o caminho em uma busca. A mudança de cenário, que evolui das criaturas demoníacas na tentação de Santo Antônio e da $A$ Crucificação para a $A$ Ressureição, favorece a perspectiva de metamorfose da doença para a morte e da morte para a cura e das mazelas da vida humana, porque a vida náo acabaria na morte. $\mathrm{O}$ frontispício aberto do altar com a imagem A Ressurreição, espaço destinado à figura do Cristo Cósmico Curandeiro, ocupa a função mercurial de atrair as almas para Plutão, deus dos mortos, cumprindo a mesma função descrita no mito, mas também funciona com um lembrete aos adeptos da Antroposofia de que morreremos precocemente se não metamorfosearmos os conflitos em um equilíbrio disciplinador.

Essa reunião de elementos ricos em simbologia reorganizada pela racionalidade científica da Naturphilosophie com aspectos estéticos da arte gótica alemã, dos mistérios da alquimia e dos recursos mitológico, garante para as medicinas neorromânticas como para a Antroposofia um espaço de status no mercado da cura. Reencantar a cura dos problemas é atualmente mais 
importante que resolver os sintomas. A performance pendular entre os demônios, os vícios, as mazelas, passa a ressignificar as batalhas da humanidade claudicante.

\section{REFERENCIAS}

BASTOS, Raquel Littério de. Corpo e Saúde na Antroposofia: Bildung como cura. São Paulo: LiberArs, 2018.

BÉGUERIE-DE PAEPE, Pantxika; LORENTZ, P. (dir.). Grünewald et le retable d'Issenheim. Regards sur un chef-d'oeuvre. Paris: Somogy Editions d'art, 2007. BELTING, Hans. An anthropology of images. Princeton: Princeton University Press, 2011.

FOUCAULT, Michel. Vigiar e Punir: nascimento da prisão. Petrópolis: Vozes, 2010 GELL, Alfred. Art and Agency: an Anthropological Theory. Oxford: Oxford University Press, 1998.

HIGUET, Etienne. A Crucifixão de Matthias Grünewald à luz de uma teologia protestante da imagem. Revista Eletrônica Correlatio, n. 16, dez 2009. HIGUET, Ettienne. A. Representação do Cristo no expressionismo alemão. Observatório da religiāo, v. 1, n. 2, ago./dez. 2014, p. 76-91.

HÖRISCH, Jochen. Der Mittler und die Wut des Verstehens. Schleiermachers frühromantische Anti-Hermeneutik. In. BEHLER, Ernst; HÖRISCH, Jochen. (Hrsg.). Die Aktualität der Frühromantik. München: Paderborn, 1987. p. 19-32. HUSEMANN, Friedrich; WOLFF, Otto. A imagem do homem como base da arte médica: patologia e terapêutica. São Paulo: Associação Beneficente Tobias, 2007.

LA CRUCIFIXION DE GRÜNEWALD. Neorbe, 2007. Anônimo. Disponível em: http://www.namurois.org/castelluna/?post/2007/04/10/La-Crucifixion-de-Grunewald. Acesso em: 19 maio 2009. 
LUZ, M. T.; WENCESLAU, L. D. Goethe, Steiner e o nascimento da arte de curar antroposófica no início do século XX. Revista Crítica de Ciências Sociais, v. 98, 2012.

MAAS, Wilma Patricia M. D. Ininteligibilidade e hermenêutica n'as afinidades eletivas, de Goethe. Olho d'água, São José do Rio Preto, v. 2. n. 2, p. 1-200, 2010 MORAES, W. A. Elaboração de uma medicina ampliada pela Antroposofia. In: MORAES, W. A. Medicina Antroposófica: um paradigma para o século XXI. São Paulo: ABMA, 2007.

QUANT, Jaime Morales. Variaciones sobre la herencia em la narrativa de Edwidge Danticat. Cuadernos del GESCAL, ano 3, n. 1, out. 2016

SCHLAFFER, Heinz. Namen und Buchstaben in Goethes "Wahlverwandtschaften". In: BOLZ, N. W. (ed.). Goethes Wablverwandtschaften: Kritische Modelle und Diskursanalysen zum Mythos Literatur. Hildesheim: Gerstenberg, 1981. p. 211-229.

SETZER, Valdemar W. O bem e o mal do ponto de vista da Antroposofia. 2011. Disponível em <http://www.ime.usp.br/ -vwsetzer/antrop/bem-mal.html>. Acesso em: 21 nov. 2015.

STEINER, Rudolf. Doença e cura. Associação Brasileira de Medicina Antroposófica: São Paulo, 1998.

WASHINGTON, Peter. O babuino de madame Blavatsky: místicos, médiuns e a invenção do guru ocidental. Rio de Janeiro: Record, 2000.

WITZEL, Denise Gabrel; SILVEIRA, Andréia Aparecida T. S. Uma análise discursiva da iconografia da crucificação. Estudos linguísticos, Sinop, v. 10, n. 22, p. 92-112, jul./dez. 2017.

Recebido em: 22/10/2018

Aprovado em: 07/01/2019 
